\title{
RESEARCH
}

Open Access

\section{Effect of pawpaw leaf and seed meal composite mix dietary supplementation on haematological indices, carcass traits and histological studies of broiler chicken}

\author{
O. D. Oloruntola ${ }^{1,2}$ (D)
}

\begin{abstract}
Background: The use of phytogenic feed supplement is now being considered in broiler production for enhancing their performance and health status. In this 42-day feeding trial, the effects of a diet supplemented with pawpaw leaf and seed meal composite mix (PCM) on hematological indices, carcass, internal organs weights, and histology of the liver and testis of broiler chickens was assessed.

Methods: Total number of 396 1-day-old Arbor Acres broiler chicks were distributed to six dietary treatments: (diet 1; 0.0 \% PCM), (0.2 \% PCM), (0.4 \% PCM), (0.6 \% PCM), (0.8 \% PCM), (1.0\% PCM). The relative internal organ weights and hematological indices were determined. The liver and testistical samples were taken for histopathological examination.

Results: White blood cell (WBC) counts of birds fed PCM supplemented diets were similar/comparable to that of the birds fed the control diet; however, the highest $(P<0.05)$ counts were recorded in birds fed diets 2 and 6. The hemoglobin concentration $(\mathrm{Hbc})$ and packed cell volume $(\mathrm{PCV})$ of birds fed PCM supplemented diets were similar $(P>0.05)$ to those fed the control diet, except for those fed diet 6 had significantly $(P<0.05)$ lower Hbc and PCV. The carcass and relative internal organ weight of the broiler chickens were not affected $(P>0.05)$ by the PCM supplementation. The dietary PCM supplementation produced a marked proliferation of polymorphonuclear and mononuclear cells, activation of liver macrophages system, the Kupffer cells in the liver of the birds. There were also reduced spermatogenic activities in seminiferous tubules, congestion of seminiferous tubules, tunica albuginea, and medial hypertrophy of the blood vessels in birds fed the 0.4 to $1.0 \%$ PCM supplemented diets.

Conclusion: Dietary PCM supplementation supports normal hemapoietic processes and normal carcass and internal organ development. However, dietary PCM supplementation produced some pathological changes in the liver and testis of the birds.
\end{abstract}

Keywords: Avian, Blood composition, Carcass traits, Pathological changes, Phytogenics

\footnotetext{
Correspondence: oloruntoladavid@gmail.com;

olugbenga.oloruntola@aaua.edu.ng

${ }^{1}$ Department of Animal Science, Adekunle Ajasin University, Akungba Akoko,

Nigeria

${ }^{2}$ Department of Agricultural Technology, The Federal Polytechnic, Ado Ekiti,

Nigeria
} 


\section{Introduction}

The use of growth promoters has been adopted for several decades in animal production to enhance the animals' growth performance, increase their prime cuts yield, and decrease intramuscular fat deposition (Valenzuela-Grijalva et al. 2017). However, due to the human and animal health risks associated with the use of synthetic feed additives as growth promoters in meat production, synthetic or antibiotic growth promoters are now being rejected in many countries (Gonzalez and Angeles 2017). The dietary supplementation with phytobiotics, phytogenic feed additives, phytochemical feed additives, and herbal supplements or ingredients are now being considered as alternatives to the synthetic growth promoters (Fallah et al. 2013; Oloruntola et al. 2018a; Oloruntola et al. 2018b). The phytochemicals have antimicrobial, anti-stress, antioxidant, and immunomodulatory properties which made them potential growth promoters in animal production (ValenzuelaGrijalva et al. 2017).

Parts of various plants that are of medicinal importance had been used as supplements and or ingredient in the production of livestock to achieve various purposes of performance and health importance (Oloruntola et al. 2016c; Oloruntola and Ayodele 2017; Oloruntola 2018; Wenk 2003). Seeds and leaves of pawpaw were reported to neutraceutical and antioxidant properties (Kadiri et al. 2016). Pawpaw contains a high content of vitamin A, B, and $C$; papain; and chymopapain. The leaves and seeds of papaya contain 2,2-diphenyl-1-piccrlhydrazyhydrate (7.8 $\mathrm{mg} / \mathrm{ml}$ and $1.0 \mathrm{mg} / \mathrm{ml}$ ), phenol (424.89 mg GAE/ $100 \mathrm{~g}$ dry weight and $30.32 \mathrm{mg}$ GAE/100 g dry weight), and flavonoid (333.14 mg GAE/100 g dry weight and $59.54 \mathrm{mg}$ GAE/100 g dry weight), respectively (Maisarah et al. 2014). There could be interactions of the bioactive compounds in these two phytogens (pawpaw leaves and seeds), which needs to be examined (Oloruntola et al. 2018c). It was reported that medicinal plants could serve as anti-fertility agents (Nurcahyani et al. 2018). In particular, extract of papaya seeds was reported to cause various pathological changes in the reproductive organs of the animals, such as the shrunken of testis tubules, vacuolation of Sertoli cells, and abnormalities of germ cells among others (Lohiya et al. 2002). The hepatotoxic property that is dose and duration/time dependant was also reported for pawpaw by Amazu et al. (2014). Although, positive results have been reported when pawpaw plant parts are used as supplements or ingredients in animal feed (Hassan et al. 2014; Oloruntola et al. 2018a, c), pathological investigations on effects of the use of pawpaw leaves and seeds as dietary supplements or ingredients on broiler chickens are very few. Therefore, this study intended to investigate the effect of pawpaw leaf and seed meal composite mix dietary supplementation on haematological indices, carcass traits, and histopathological studies of broiler chickens.

\section{Materials and methods}

Ethical approval, experimental site, and pawpaw leaf and seed meal composite mix preparation and analysis

Prior to the commencement of this experiment, the approval for the use of animal and animal protocol was given by the Research and Ethics Committee of Agricultural Technology Department, The Federal Polytechnic, Ado Ekiti, Nigeria. Thereafter, the experiment was conducted at the Agricultural Technology Department Teaching and Research Farm. The experimental site has mean annual rainfall of $1247 \mathrm{~mm}$ and mean annual temperature of 26.2 ${ }^{\circ} \mathrm{C}$ and was situated at $437 \mathrm{~mm}$ above sea level; latitudes of $7^{\circ} 37^{\prime} \mathrm{N}$ and $7^{\circ} 12^{\prime} \mathrm{N}$ and longitudes of $5^{\circ} 11^{\prime} \mathrm{E}$ and $5^{\circ}$ $31^{\prime}$ E (Oloruntola et al. 2016b).

Pawpaw leaves and ripe fruits were plucked from pawpaw trees within the premises of The Federal Polytechnic, Ado Ekiti, Nigeria. The fresh pawpaw leaves were shopped into smaller pieces with a sharp stainless knife and thereafter spread lightly on tarpaulin under a shed to air-dry for about 2 weeks, milled (100 $\mu \mathrm{m}$ size) to produce pawpaw leaf meal (PLM). Seeds were scooped out of ripped pawpaw fruits with clean human hands, washed gently with water, drained, and spread lightly on tarpaulin under a shed to air-dry for about 3 weeks. The dried pawpaw seeds were thereafter milled (100 $\mu \mathrm{m}$ size) to produce pawpaw seed meal (PSM). Three portions of PLM and one portion of PSM were mixed to form a pawpaw leaf meal and seed meal composite mix (PCM). The PCM were thereafter analysed for saponin (Brunner, 1984), tannin (Aina et al. 2012), terpenoid (Sofowora 1993), vitamin C (Benderitter et al. 1998), 2,2-diphenyl-1-piccrlhydrazyhydrate (Gyamfi et al. 1999), and ferric reducing antioxidant property (Pulido et al. 2002).

\section{Experimental diets}

Two basal diets were formulated for the starter (0 to 21 days) and grower/finisher phase (22 to 42 days) according to the recommendations NRC (1994) for broiler chicken. At each phase, the basal diets were divided into six equal portions and named diets 1 to 6 . Diet 1 contained 0\% PCM supplementation, diet 2 was supplemented with $0.2 \%$ PCM, while diet 3 , diet 4 , diet 5 , and diet 6 were supplemented with $0.4,0.6,0.8$, and $1.0 \%$ PCM, respectively. The crude protein and crude fibre of the basal diets were determined (AOAC 1995).

\section{Birds, housing, and experimental design}

Three hundred ninety-six 1-day-old Arbor Acres broiler chicks were distributed to six dietary treatments; comprising of 66 birds per treatment and 11 birds per 
replicate in a completely randomized design. The floor of the pen $(200 \times 110 \mathrm{~cm})$ that housed the birds in each replicate was covered with wood shavings. The temperature of the house was maintained within $31{ }^{\circ} \mathrm{C} \pm$ 2 for the first week of brooding and reduced by $2{ }^{\circ} \mathrm{C}$ after each consecutive 7 days until the house temperature was $26{ }^{\circ} \mathrm{C} \pm 2$. Twenty-three hours light was provided per day. The birds were fed ad libitum throughout the 42 days of the experiment.

\section{Chicken slaughtering procedure, sample collection and analysis, carcass trait and internal organ evaluation, and histological study}

On day 42 of the experiment, three birds per replicate were selected for sacrifice, tagged, and weighed. The birds were stunned and their jugular vein was cut with clean, sharp stainless knife. The blood was allowed to flow into EDTA bottle for hematological studies. The hematological indices values were determined within $2 \mathrm{~h}$ post collection as described by Shastry (1983).

After the blood collection, the slaughtered birds were de-feathered, eviscerated, and dressed. The dressed weight and dressed percentage of the slaughtered bird were estimated. Thereafter, the liver, heart, lung, bile, gizzard, spleen, and bursa were excised out with a clean surgical blade, blotted with tissue paper, weighed, and expressed as the percentage of slaughtered weight. The testes of one slaughtered bird from each replicate were also taken out. The liver and testes (one each/replicate) were separated for histological study, fixed in $10 \%$ neutral-buffered formalin, dehydrated in a graded alcohol series $(70 \%, 90 \%$, absolute ethanol), cleared with methyl benzoate, and embedded in paraffin wax.

Sections of $5 \mu \mathrm{m}$ were cut and stained on glass slides with hematoxylin and eosin stain for light microscopic examination (Bancroft et al. 1996; Oloruntola et al. 2017). Stained sections were examined by light microscope and photographed using a digital camera.

\section{Data analysis}

The model: $X_{\mathrm{ab}}=\mu+\alpha_{\mathrm{a}}+\beta_{\mathrm{ab}}$ was used in this experiment. Where $X_{\mathrm{ab}}$ is any of the response variables, $\mu$ is the overall mean, $\alpha_{\mathrm{a}}$ is the effect of the $i$ th treatment ( $a$ $=$ diets $1,2,3,4,5$, and 6 ), and $\beta_{\mathrm{ab}}$ is the random error due to experimentation. All data were subjected to ANOVA using SPSS version 20 (SPSS 2011). Duncan multiple range tests (Duncan 1955) were used to determine the difference among means.

\section{Results}

Pawpaw leaf and seed meal composite mix and experimental diets

Table 1 shows the phytochemical composition and antioxidant properties of pawpaw leaf and seed meal composite
Table 1 Chemical composition and antioxidant properties of pawpaw leaf and seed meal composite mix

\begin{tabular}{ll}
\hline Parameters & Quantity \\
\hline Plant metabolites (mg/g) & \\
Tannin & $6.17 \pm 0.01$ \\
Terpenoid & $12.82 \pm 0.00$ \\
Cardiac glycoside & $18.59 \pm 0.00$ \\
Saponin & $4.72 \pm 0.11$ \\
Steroid & $5.84 \pm 0.01$ \\
Antioxidant parameters & \\
FRAP (mg/g) & $128.53 \pm 0.33$ \\
DPPH (\%) & $48.09 \pm 0.17$ \\
Vitamin C (mg/g) & $21.62 \pm 0.01$ \\
\hline
\end{tabular}

FRAP ferric reducing antioxidant property, DPPH 2,

2-diphenyl-1-piccrlhydrazyl hydrate

mix, while the composition of experimental basal diets for starter and grower phases is shown in Table 2.

\section{Hematological indices}

Effects of pawpaw leaf and seed meal composite mix (PCM) supplementation on hematological indices of broiler chickens are shown in Table 3. Although the white blood cell (WBC) counts of birds fed PCM supplemented diets were similar/comparable to that of the

Table 2 Composition and nutrient content of experimental basal diets

\begin{tabular}{lll}
\hline Ingredients (g/kg) & Starter (1 to 21 days) & Grower (22 to 42 days) \\
\hline Maize & 426.60 & 485.60 \\
Wheat offal & 121.00 & 101.00 \\
Soybean meal & 386.90 & 347.90 \\
Vegetable oil & 22.00 & 23.00 \\
Di-calcium phosphate & 18.00 & 17.00 \\
Limestone & 14.00 & 14.00 \\
Premix & 3.00 & 3.00 \\
Methionine & 3.00 & 3.00 \\
Lysine & 2.50 & 2.50 \\
Salt & 3.00 & 3.00 \\
Total & 1000.00 & 1000.00 \\
Chemical analysis (g/kg DM) & \\
Crude protein & 220.00 & 205.60 \\
Crude fibre & 45.30 & 43.80 \\
Calculated analysis & & \\
ME (kcal/kg) & 2955.88 & 3000.24 \\
Ca (g/kg DM) & 10.20 & 9.30 \\
Available P (g/kg DM) & 6.00 & 5.50 \\
Methionine (g/kg DM) & 6.30 & 3.80 \\
Lysine (g/kg DM) & 11.50 & 10.30 \\
\hline
\end{tabular}

ME metabolizable energy 
birds fed the control diet, the highest $(P<0.05)$ WBC counts were recorded in birds fed diets 2 and 6 . The hemoglobin concentration ( $\mathrm{Hbc}$ ) and packed cell volume (PCV) of birds fed PCM supplemented diets were similar $(P>0.05)$ to those fed the control diet, except for those fed diet six had significantly $(P<0.05)$ lower Hbc and PCV.

\section{Carcass and relative internal organ weight}

The carcass and relative internal organ weights of the broiler chickens were similar $(P>0.05)$ across the various dietary treatments (Table 4 ).

\section{Histology}

Figures 1, 2, 3, 4, 5 and 6 show the histopathological sections of the liver. The histological hepatic cells appearances of birds fed control diet are hepatic tissues composed of hepatocytes disposed of in the sheet which are separated by sinusoids free of collections and inflammatory cells, moderate congestion of the portal vessels of polymorphonuclear cells (Fig. 1). However, the dietary PCM supplementation produced some pathological changes such as the marked proliferation of polymorphonuclear and mononuclear cells and activation of liver macrophage system, the Kupffer cells in the liver of the birds (Figs. 2, 3, 4, 5 and 6).

The histological sections of the testes are shown in Figs. 7, 8, 9, 10, 11 and 12. In birds fed 0.0 and $0.2 \%$ PCM supplemented diets, the testicular histological sections showed coils of seminiferous tubules which contain germinal epithelium with germ cells at varying degree of maturity. The interstitium is free of collection and contained interstitial cells of Leydig (Figs. 7 and 8). However, varying histological changes such as reduces spermatogenic activities in the seminiferous tubules, congestion of seminiferous tubules, tunica albuginea and interstitial, and medial hypertrophy of the blood vessels were produced by $0.4,0.6,0.8$, and $1.0 \%$ PCM supplementation in the broiler chickens (Figs. 9, 10, 11 and 12).
Table 4 Effects of pawpaw leaf and seed meal composite mix (PCM) supplementation on carcass and relative internal organs (\%SW) of broiler chickens

\begin{tabular}{lllllllll}
\hline & D1 & D2 & D3 & D4 & D5 & D6 & SEM & $P$ value \\
\hline Dressing \% & 71.23 & 71.28 & 75.51 & 79.62 & 76.07 & 75.25 & 1.11 & 0.23 \\
Liver & 1.79 & 1.76 & 1.71 & 1.73 & 1.72 & 1.73 & 0.03 & 0.97 \\
Heart & 0.34 & 0.33 & 0.31 & 0.30 & 0.34 & 0.35 & 0.01 & 0.32 \\
Lung & 0.45 & 0.45 & 0.46 & 0.42 & 0.45 & 0.45 & 0.02 & 0.98 \\
Bile & 0.13 & 0.12 & 0.11 & 0.13 & 0.11 & 0.07 & 0.01 & 0.13 \\
Gizzard & 1.99 & 2.09 & 2.45 & 2.08 & 2.45 & 2.32 & 0.06 & 0.07 \\
Spleen & 0.14 & 0.15 & 0.16 & 0.12 & 0.11 & 0.11 & 0.01 & 0.13 \\
Bursa & 0.15 & 0.16 & 0.16 & 0.14 & 0.15 & 0.16 & 0.01 & 0.90 \\
\hline D1:0\% PCM & & & & 0.15
\end{tabular}

D1: 0 \% PCM (control); D2: 0.2 \% PCM, D3: 0.4 \% PCM; D4: 0.6 \% PCM, D5: 0.8 $\%$ PCM; D6: $1.0 \%$ PCM

SEM standard error of means

\section{Discussion}

Hematological indices had been recognised as one of the indicators for assessing the health status of animals (Oloruntola et al. 2016a). The immunomodulatory effect of phytogenic feed supplements or ingredients in animals had been reported (Oloruntola et al. 2016a) and the fact that WBC count recorded for birds fed PCM supplemented diets were comparable to WBC recorded in birds fed the control diet in this study may imply that the ability of these birds to fight infection, to defend their bodies against foreign organisms' invasion, to produce and distribute/transport antibodies were not compromised by the dietary PCM supplementation. In addition, the observed comparable values recorded for hemoglobin concentration $(\mathrm{HBc})$ and packed cell volume (PCV) in the birds fed the control diet and diets 2, 3, 4, and 5 indicate nutritional adequacy and improvement/ stability of haematological profile with PCM dietary supplementation from 0.0 up to $0.8 \%$. The reduction of the $\mathrm{HBc}$ and PCV values in birds fed diet 6 (1.0\% PCM dietary supplementation) may indicate an anemic condition in the birds, possibly due to various factors among which could be impaired utilization of essential vitamins

Table 3 Effects of pawpaw leaf and seed meal composite mix (PCM) supplementation on hematological indices of broiler chickens

\begin{tabular}{lllllllll}
\hline & D1 & D2 & D3 & D4 & D5 & D6 & SEM & $P$ value \\
\hline White blood cells $\left(\times 10^{9} / \mathrm{l}\right)$ & $3.15^{\mathrm{abc}}$ & $4.05^{\mathrm{a}}$ & $3.45^{\mathrm{ab}}$ & $2.26^{\mathrm{c}}$ & $2.90^{\mathrm{bc}}$ & $4.10^{\mathrm{a}}$ & 0.18 & 0.01 \\
Red blood cells $\left(\times 10^{6} / \mathrm{l}\right)$ & 2.50 & 2.50 & 2.25 & 2.45 & 2.40 & 2.25 & 0.04 & 0.12 \\
Hemoglobin conc. $(\mathrm{g} / \mathrm{dl})$ & $9.15^{\mathrm{ab}}$ & $9.80^{\mathrm{a}}$ & $8.95^{\mathrm{b}}$ & $9.50^{\mathrm{ab}}$ & $9.90^{\mathrm{a}}$ & $8.10^{\mathrm{c}}$ & 1.67 & 0.01 \\
Packed cell volume (\%) & $27.50^{\mathrm{ab}}$ & $29.51^{\mathrm{a}}$ & $27.00^{\mathrm{b}}$ & $28.52^{\mathrm{ab}}$ & $29.75^{\mathrm{a}}$ & $24.53^{\mathrm{c}}$ & 0.49 & 0.01 \\
Mean cell volume (fl) & 110.05 & 118.25 & 120.80 & 117.10 & 124.00 & 109.05 & 2.13 & 0.28 \\
Mean cell hemoglobin (pg) & 33.25 & 33.20 & 33.06 & 33.15 & 33.25 & 33.05 & 0.02 & 0.07 \\
Mean cell hemoglobin conc. $(\mathrm{g} / \mathrm{dl})$ & 36.65 & 39.25 & 40.01 & 39.05 & 41.25 & 36.00 & 0.71 & 0.27 \\
\hline
\end{tabular}

Means within a row with different letters are significantly different $(P<0.05)$

D1: 0 \% PCM (control); D2: 0.2 \% PCM, D3: 0.4 \% PCM; D4: 0.6 \% PCM, D5: 0.8 \% PCM; D6: 1.0 \% PCM

SEM standard error of means 


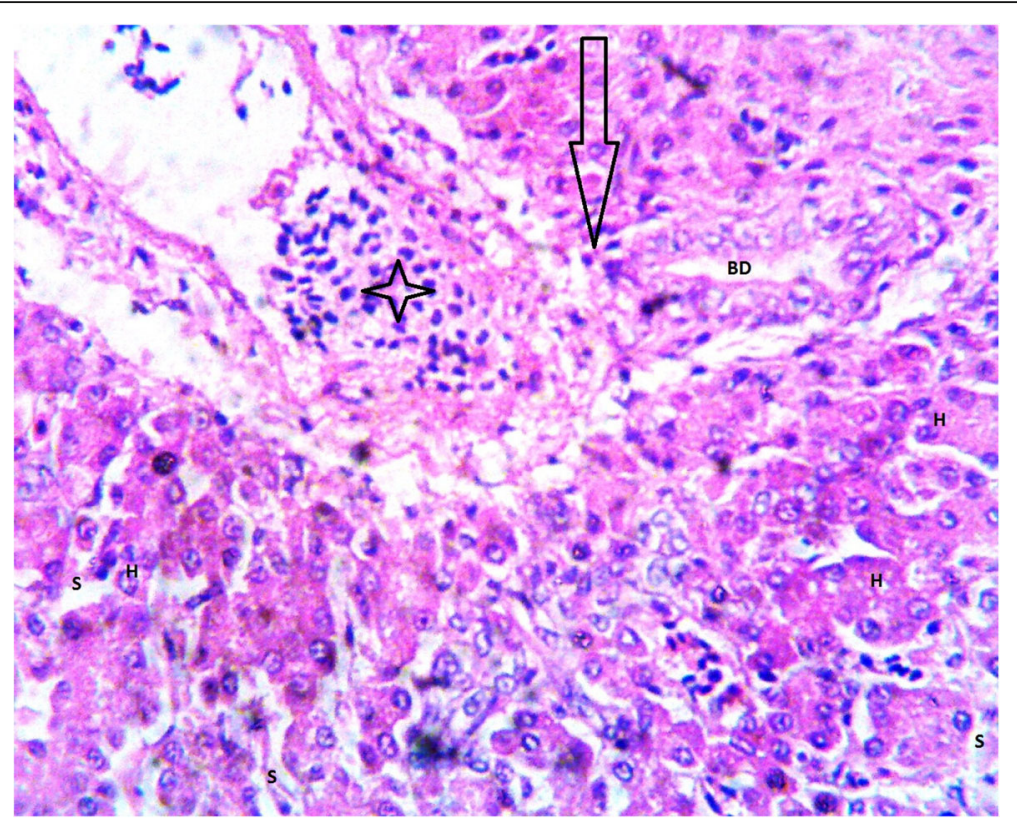

Fig. 1 Representative micrograph of liver section $(\times 400)$ of broiler chicks fed $0.0 \%$ PCM supplemented diet. This section shows the hepatic tissues composed of hepatocytes $(\mathrm{H})$ disposed of in the sheet and is separated by sinusoids $(\mathrm{S})$ free of collections and inflammatory cells, the portal vessels (arrow) shows moderate congestion of polymorphonuclear cells (star)

and minerals (vitamin $\mathrm{B}_{2}, \mathrm{~B}_{6}$, and iron) needed for erythropoiesis. At excessive amount, some phytochemicals may cause a deficit in normal absorption of nutrients and in particular, may form insoluble complexes with minerals (Chukwuebuka and Chinenye 2015). However, this observation may not have predict health implication because the values recorded for $\mathrm{HBc}(8.10-$ $9.90 \mathrm{~g} / \mathrm{dl})$ and PCV $(24.53-29.75 \%)$ in the birds fed $1.0 \%$ PCM supplemented diet falls within the normal range of 7.50-13.1 g/dl (HBc) and 26.00-45.20\% (PCV) reported by Mitruka and Rawnsley (1977) for healthy birds. Akintomide et al. (2018) reported that the blood parameters

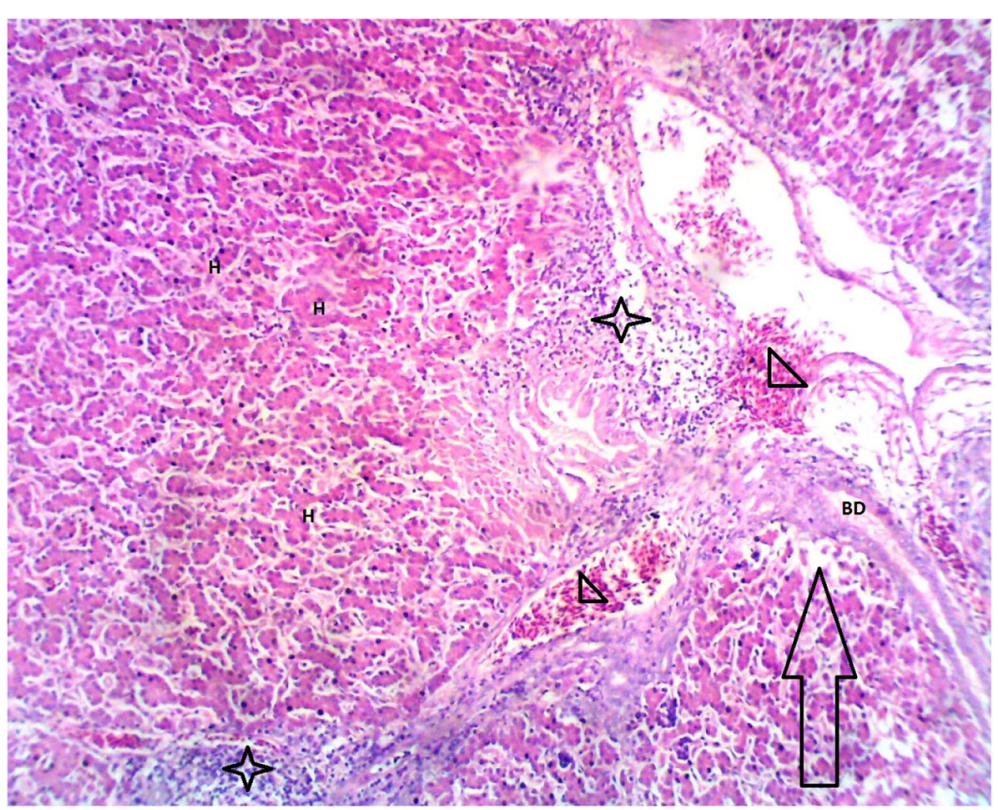

Fig. 2 Representative micrograph of liver section $(\times 400)$ of broiler chicks fed 0.2\% PCM supplemented diet. This section shows the hepatic composed of the hepatic portal region (arrow) composed of the hepatic vessels, lymphatics, and bile duct (BD). The section shows marked proliferation of polymorphonuclear and mononuclear cells (arrow and star) 


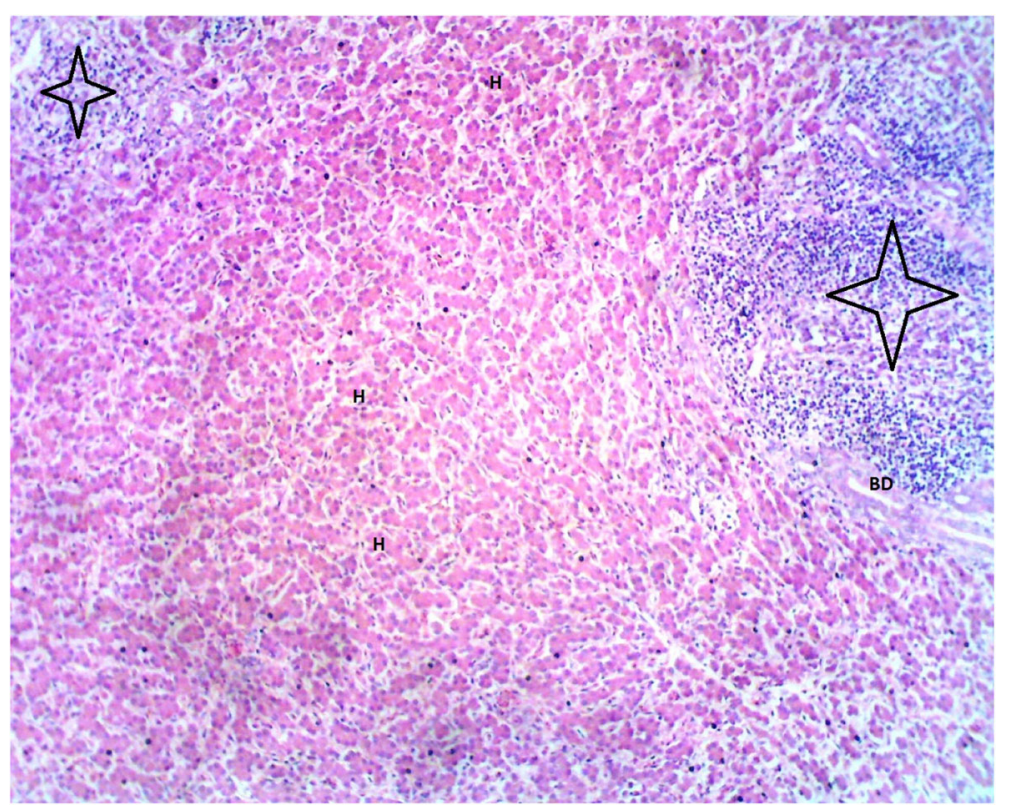

Fig. 3 Representative micrograph of liver section (× 400) of broiler chicks fed 0.4\% PCM supplemented diet. This section shows liver parenchymal cells and marked proliferation of polymorphonuclear and mononuclear cells (star)

of cockerels fed diets containing 0 to $15 \%$ neem leaf meal were not affected, while Oloruntola et al. (2018a) also recorded a similar blood indices values between the birds fed the control diet and 5\% pawpaw leaf meal inclusive diet. Therefore, it is suspected that the reduced $\mathrm{HBC}$ and PCV values recorded in birds fed diet $6(1.0 \%$ PCM dietary supplementation) in the present study could not have been due to the phyto-constituents of
PCM, but probably due to other factors that were not studied in this work but has notable interaction with PCM dietary supplementation at $1.0 \%$ and produced impact on the affected blood indices in the experimental birds.

An abnormal change (increase/decrease) in the relative internal organs' weights is one of the indicators for the animals' response to toxins in their feed (Ayodele et al.

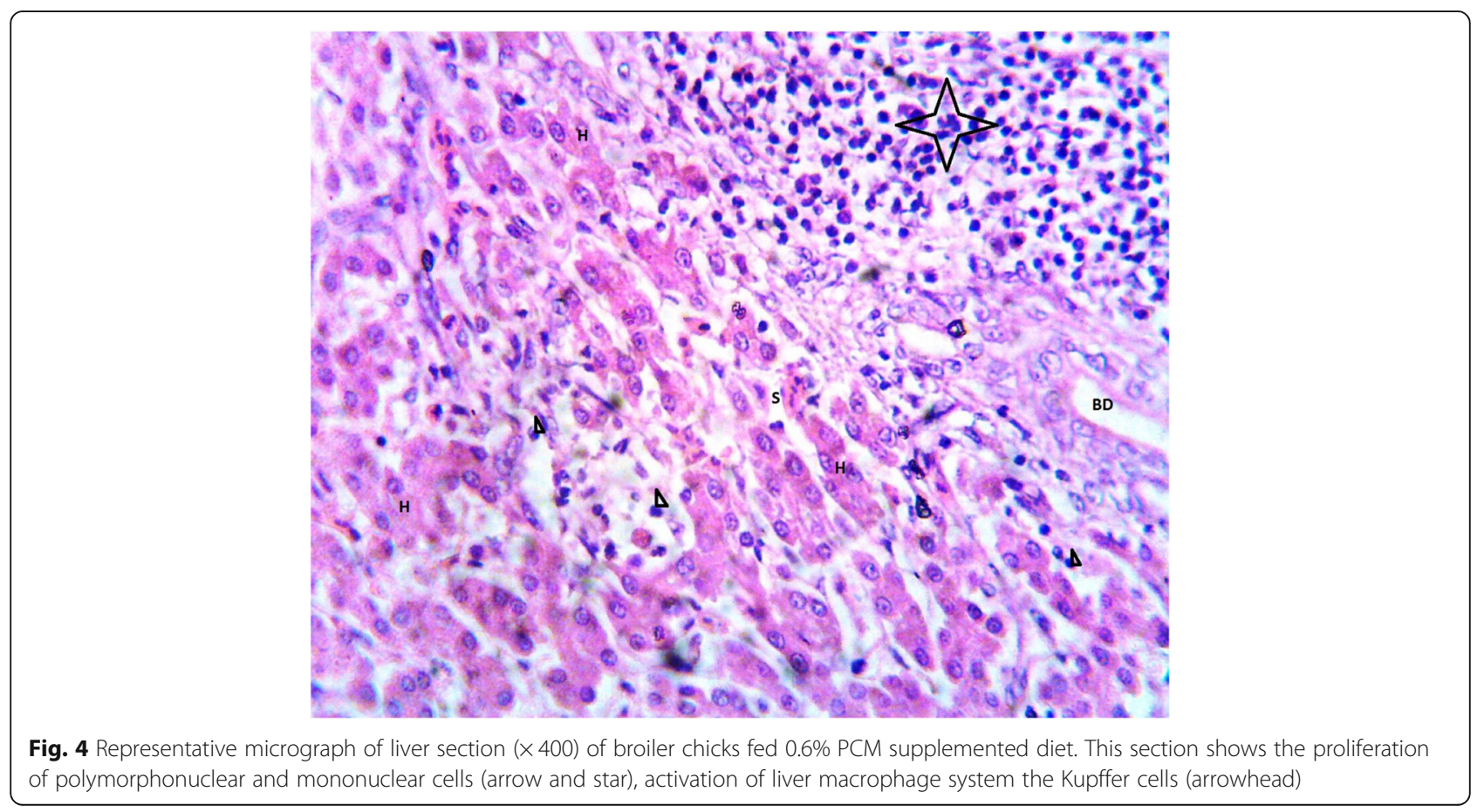




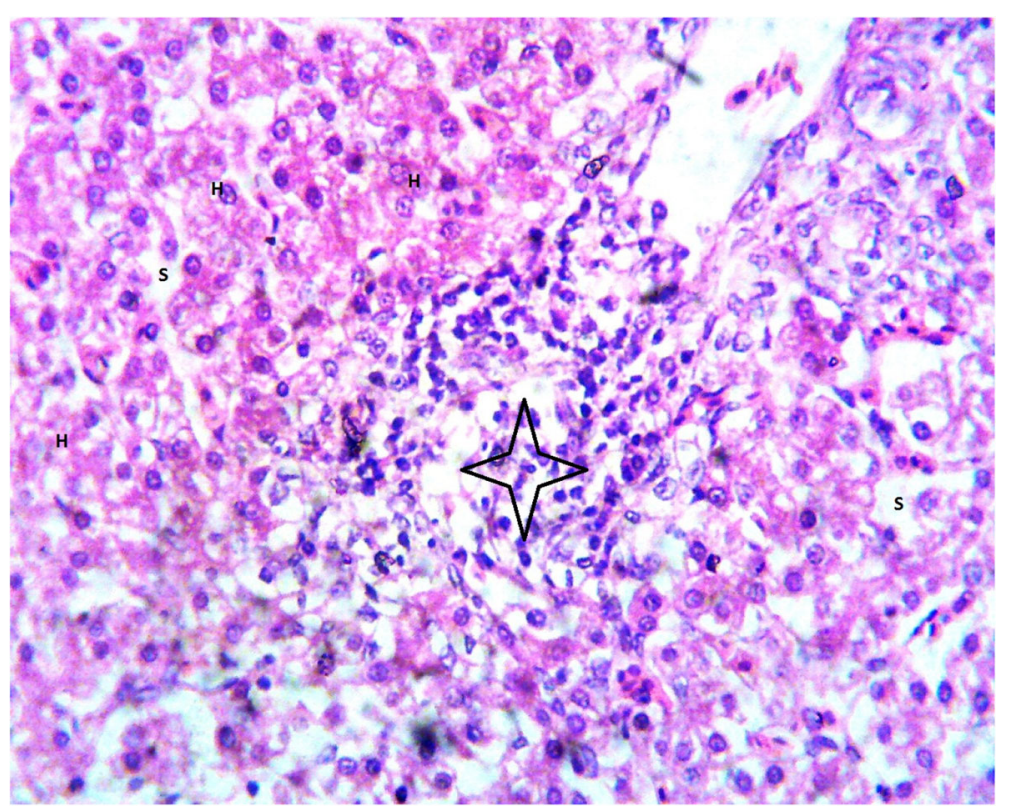

Fig. 5 Representative micrograph of liver section $(\times 400)$ of broiler chicks fed 0.8\% PCM supplemented diet. This section shows activation of liver macrophage system the Kupffer cells (star)

2016). The stable relative internal organs weight of the birds across all the dietary treatment groups in this study suggests that the health status of these birds were not negatively affected by the PCM supplementation. Further studies are however required to ascertain this hypothesis. This result disagreed with an earlier report of Oloruntola et al. (2018a) who recorded changes in relative weight of liver of broiler fed 5\% pawpaw leaf meal supplemented diets compared to those fed the control diet. This disparity may be due to the differences between the PCM inclusion/supplementation levels among the two experiments. By implication, higher dietary PCM levels may produce a change in the relative weight of the broiler chickens' liver. However, a further study is required to support this hypothesis.

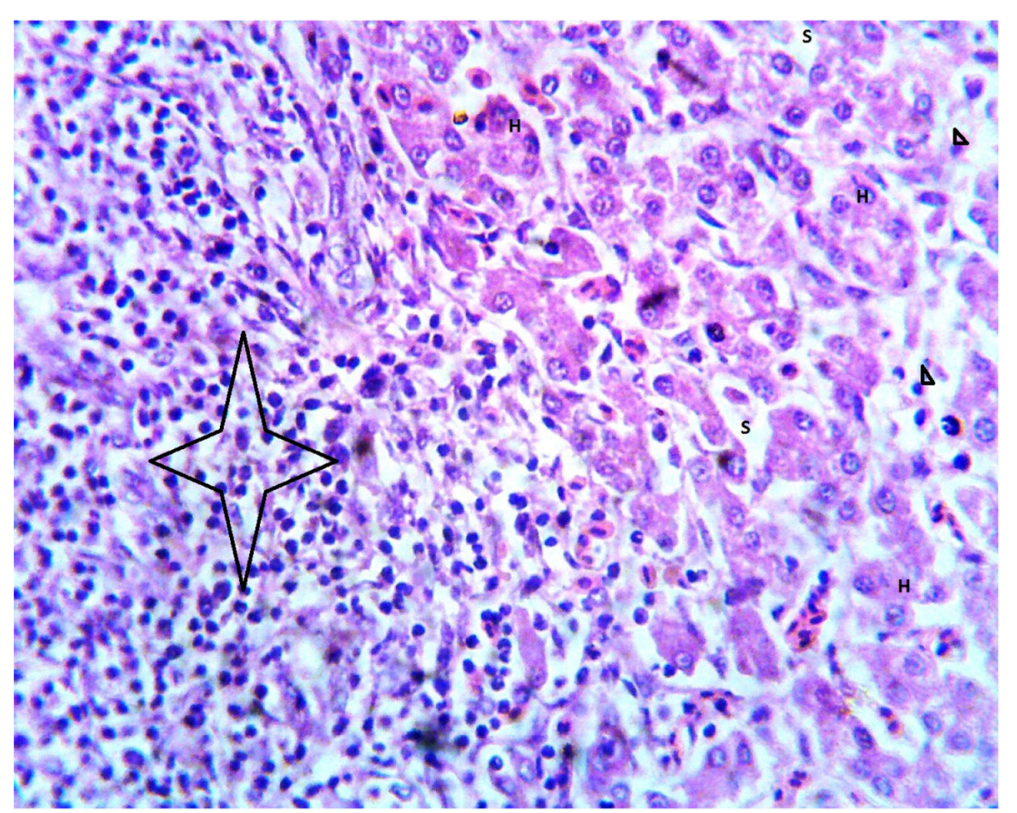

Fig. 6 Representative micrograph of liver section $(\times 400)$ of broiler chicks fed 1.0\% PCM supplemented diet. This section shows the proliferation of polymorphonuclear and mononuclear cells (arrow and star), activation of liver macrophage system, the Kupffer cells (arrowhead) 


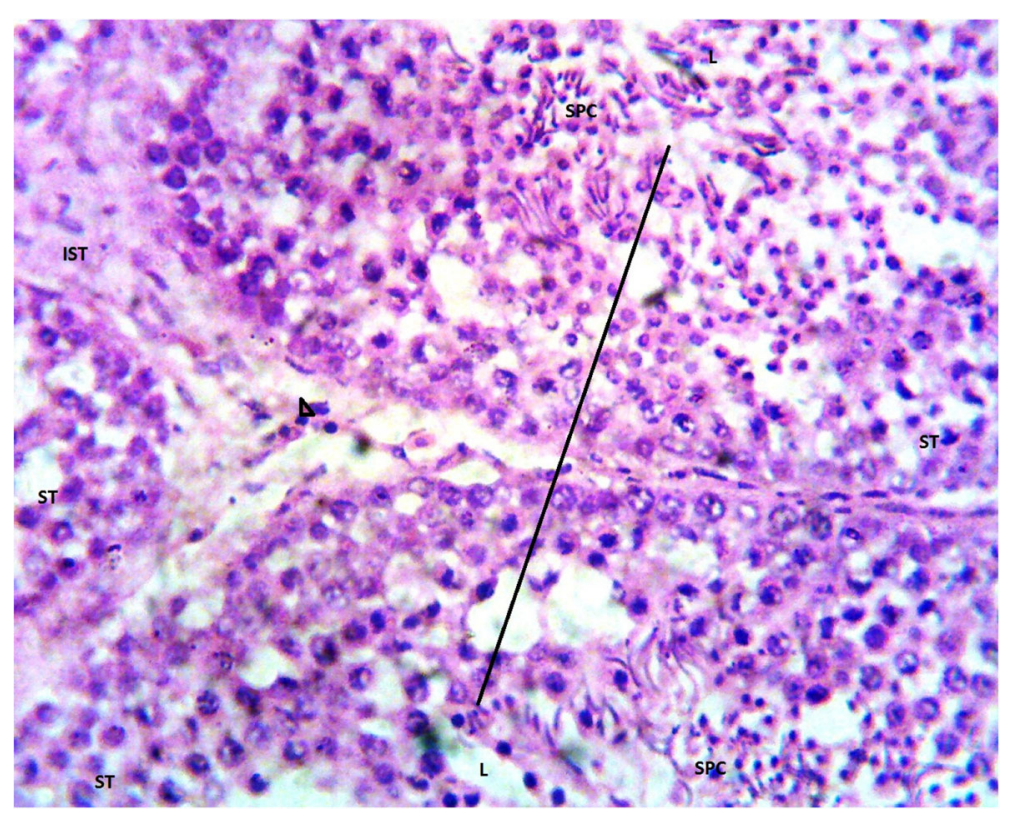

Fig. 7 Representative micrograph of testis section $(\times 400)$ of broiler chicks fed 0.0\% PCM supplemented diet. This section shows the testicular tissue composed of coils of seminiferous tubules (ST). The ST contains germinal epithelium with germ cells at varying degree of maturity (line). The interstitium (IST) is free of collection and contained interstitial cells of Leydig (arrowhead)

Among the numerous functions of the liver is the processing of nutrient absorbed from the intestine and secretion of an alkaline fluid (bile) which functions in the digestion of fat and toxic substance removal from the living organism (Oloruntola 2018). The variation of the histological appearances of the liver cells of birds fed 0.2 to $1.0 \%$ dietary PCM supplementation compared to those fed the control diet may be related to phytochemicals/anti-nutritional factors present in PCM. According to Soetan and Oyewole (2009), anti-nutrients may present some activities which though not deeply understood, but may cause histological changes in animals. Kupffer cells are principal liver cells for phagocytosis, proinflammatory cytokines production, and antigen

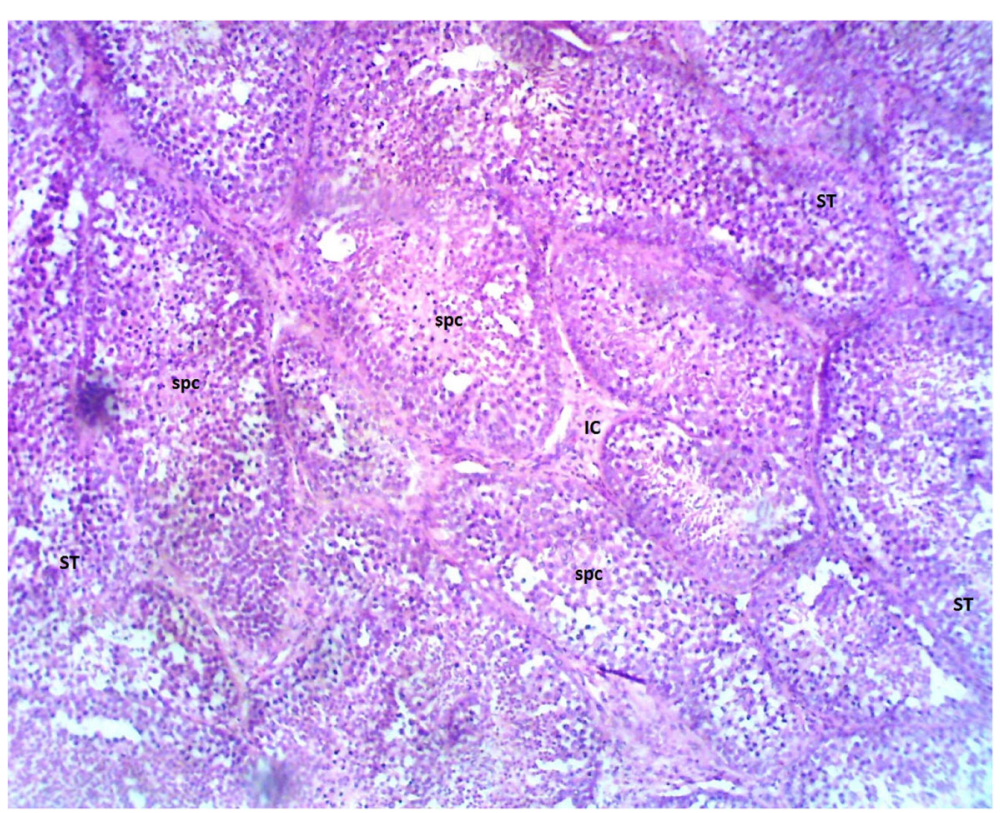

Fig. 8 Representative micrograph of testis section $(\times 400)$ of broiler chicks fed 0.2\% PCM supplemented diet. This section appears as in Fig. 7 above. SPC sperm cells, ST seminiferous tubules, IC interstitial cells 


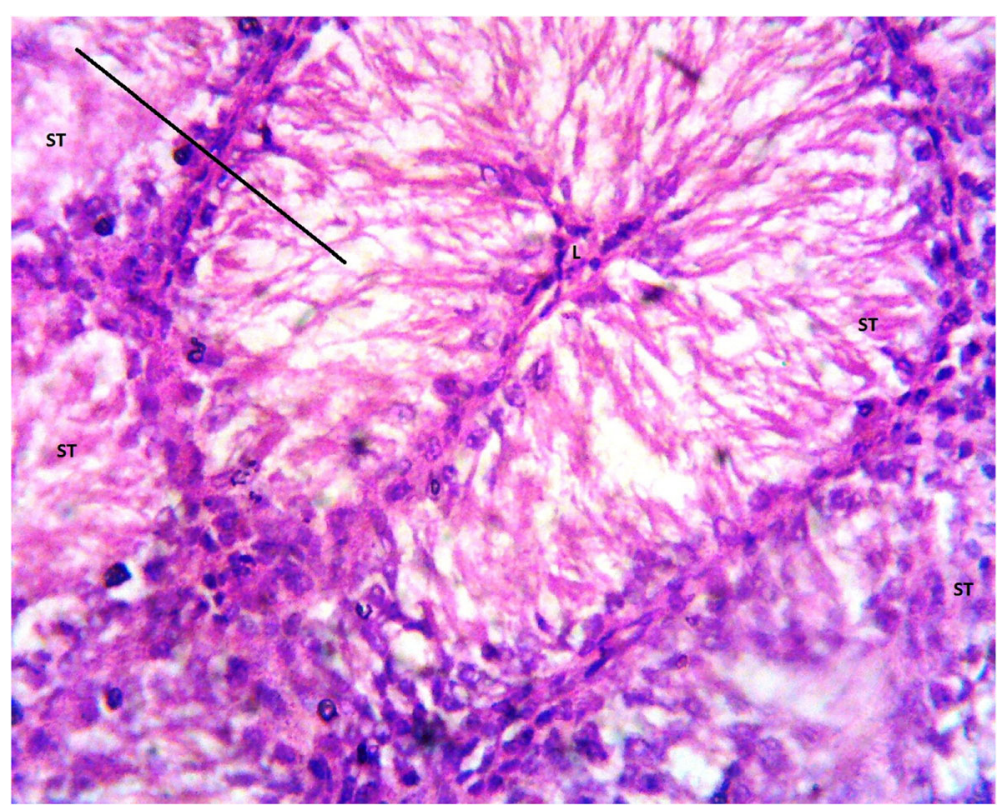

Fig. 9 Representative micrograph of testis section ( $\times 400)$ of broiler chicks fed 0.4\% PCM supplemented diet. This section shows reduced spermatogenic activities in the seminiferous tubules (ST)

presentation. They are the first cells to be exposed to materials absorbed from the intestine (Naito et al. 1997). Activation of the liver Kupffer cells as being observed in the liver of birds fed PCM supplemented diets in this study may indicate the support of the dietary treatment for the normal physiological status of the birds. This is because the Kupffer cells activation is required for the removal of or tolerance of pathogens as well as acute hepatic injury (Wick et al. 2002; Ishibashi et al. 2009). In addition, the activation of macrophages as observed in the liver of birds fed PCM supplemented diets in this study may indicate an occurrence of a multi-cellular healing process and matrix degradation during the process of fibrosis resolution (Marra et al. 2009).

The polymorphonuclear cells function in defense against tissue trauma and any inciting inflammatory

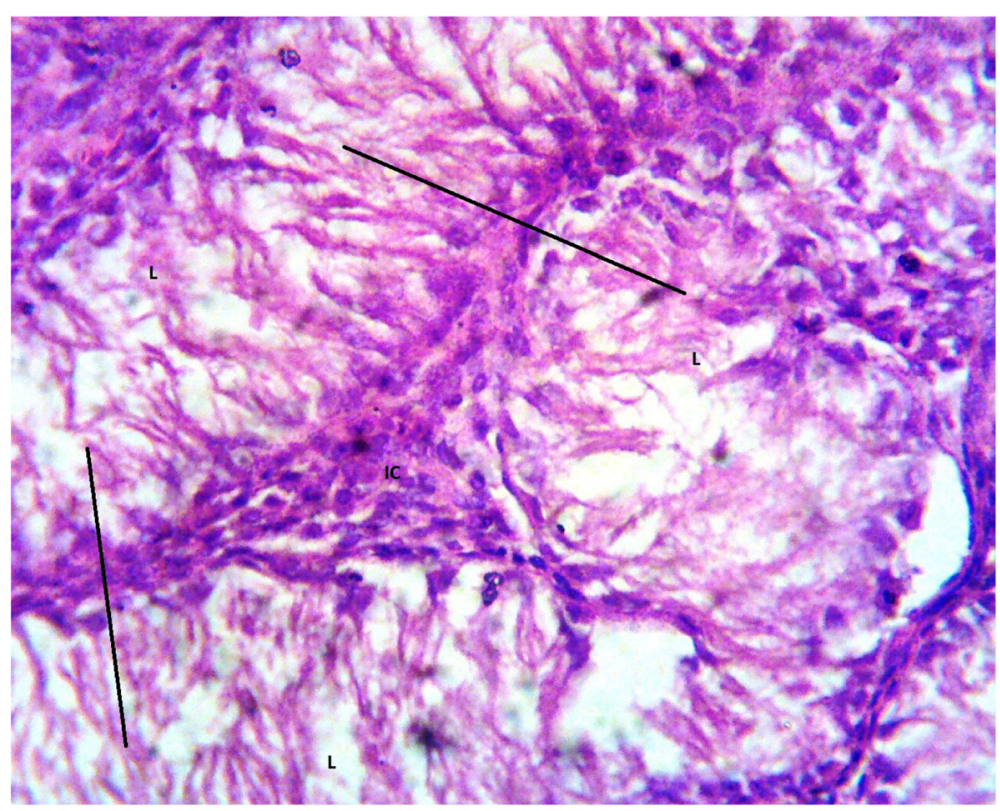

Fig. 10 Representative micrograph of testis section $(\times 400)$ of broiler chicks fed 0.6\% PCM supplemented diet. This section shows reduced spermatogenic activities in the seminiferous tubules. (Line), L lumen, IC interstitial cells 


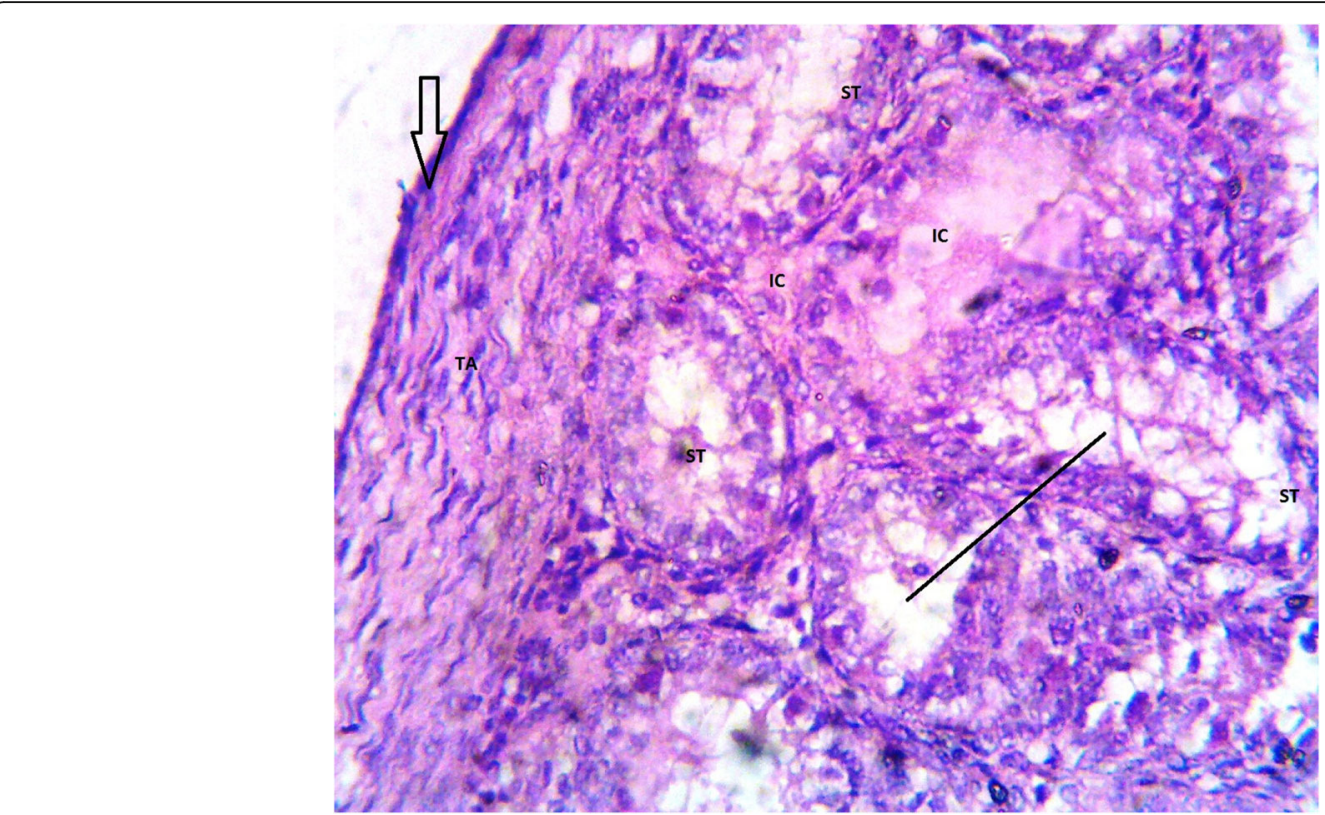

Fig. 11 Representative micrograph of testis section ( $\times$ 400) of broiler chicks fed 0.8\% PCM supplemented diet. This section shows seminiferous tubules (ST), TA tunica albuginea, IC interstitial congestion

signals among others. Therefore, the observed proliferation of polymorphonuclear cells in the birds fed PCM supplemented diets in this study may be due to the activities of anti-nutritional factors in PCM which predisposed hepatic stress in the birds.

The observed histological changes (i.e., reduces spermatogenic activities in the seminiferous tubules, congestion of seminiferous tubules, tunica albuginea, and interstitial and medial hypertrophy of the blood vessels) in testes of birds fed 0.4 to $1.0 \%$ PCM supplemented diets in this study may be the result of activities of an active ingredient (i.e., caricacin) which is present in pawpaw seeds (one of the components of PCM), but is found to cause sterility (Kobayashi et al. 2008). This

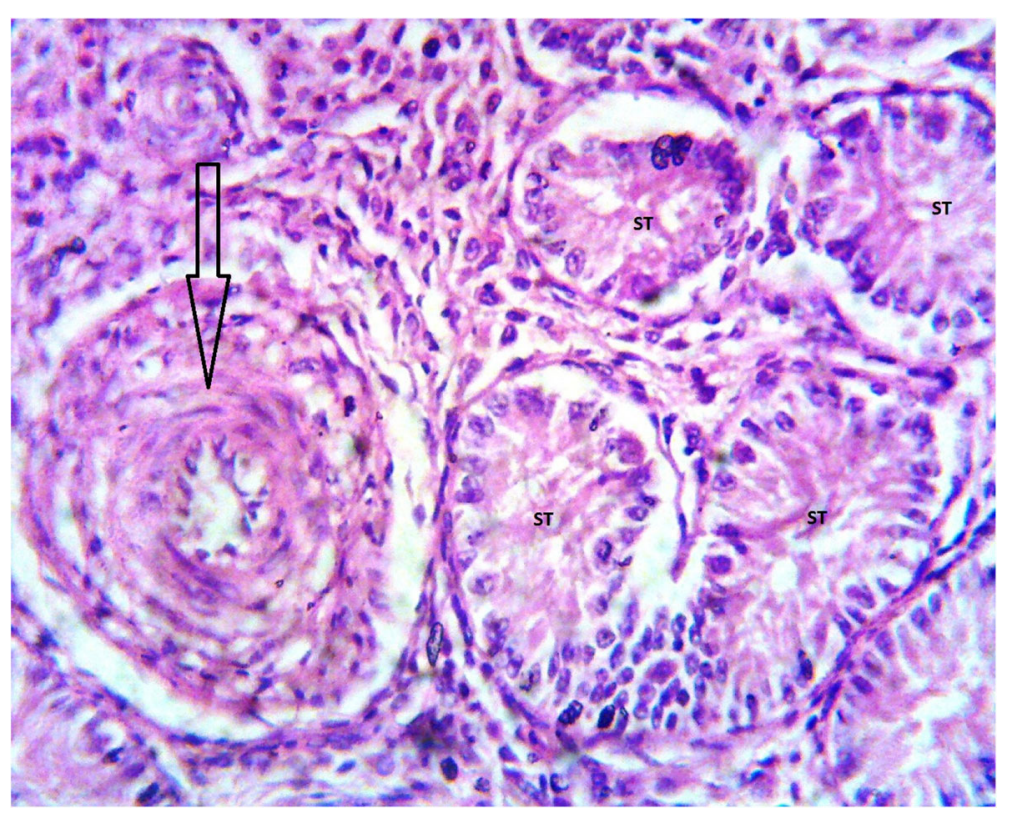

Fig. 12 Representative micrograph of testis section $(\times 400)$ of broiler chicks fed 1.0\% PCM supplemented diet. This section appears as in Fig. 11 above. The blood vessels show medial hypertrophy (arrow) 
result agreed with earlier reports of Nurcahyani et al. (2018) and Julaeha et al. (2014) who observed antispermatogenic effects of papaya seed extract in mice and rats, respectively. The compound (1,2,3,4-tetrahydropyridine-3-yl octanoate) isolated from Carica papaya seed at the concentration of $12.5 \mathrm{ng} / \mu \mathrm{l}$ was reported to cause decreased viability, motility, and an increased abnormality of the spermatozoa in rats (Julaeha et al. 2014). Another report also revealed that an oral dose $(100 \mathrm{mg} / \mathrm{kg}$ $\mathrm{BW}$ ) of ripe pawpaw seed produced degeneration of the germinal epithelium and germ cells, vacuole presence in the tubules, and Leydig cell number reduction in male albino rats (Udoh and Kehinde 1999).

\section{Conclusions}

It could be concluded that using PCM as a phytogenic feed supplement in broiler chicken diet for the period of 42 days did not pose negative effects on the normal haemopoietic processes and carcass and internal organs development. However, the dietary PCM supplementation caused some histological changes in the liver and testis of the broiler chicken.

\section{Acknowledgment}

The author would like to appreciate Mr. S.O Ayodele of the Animal Production Unit, Department of Agricultural Technology, The Federal Polytechnic, Ado Ekiti, Nigeria for his technical support and assistance.

\section{Authors' contributions}

ODO designed the study and managed all activities of the experiment. The author gathered referenced materials and prepared the draft and the final manuscript. The author read and approved the final manuscript.

\section{Funding}

This research did not receive any specific grant from funding agencies.

\section{Availability of data and materials}

Please contact author for data requests.

\section{Ethics approval and consent to participate}

The approval for the use of animal and animal protocol was given by the Research and Ethics Committee of Agricultural Technology Department, The Federal Polytechnic, Ado Ekiti, Nigeria.

\section{Consent for publication}

Not applicable.

\section{Competing interests}

The author declares he has no competing interests.

Received: 14 November 2018 Accepted: 29 July 2019

Published online: 06 August 2019

\section{References}

Aina VO, Sambo B, Zakari A, HauwaHaruna MS, Umar H, Akinboboye RM, Mohammed A (2012) Determination of nutritional and anti-nutrient content of Vitis vinifera (grapes) grown in Bomo (Area C) Zaria, Nigeria. Adv J Food Sci Tech. 4:445-448

Akintomide AA, Joseph OG, Onibi GE (2018) Heamatology and serim biochemistry of cockerels fed diets containing neem leaf meal. Appl Trop Agric. 23(1):12-16

Amazu LU, Azikiwe CCA, Njoku CJ, Osuala FN, Nwosu PJC, Ajugwo AO, Enye JC (2014) Anti-inflammatory activity of the methanolic extract of the seeds of
Carica papaya in experimental animals. Asian Pac J Trop Med.:884-886. https://doi.org/10.1016/S1995-7645(10)60212-X

AOAC (1995) Association of Official Analytical Chemistry. Official methods of analysis 16th ed., Washington DC

Ayodele SO, Oloruntola OD, Agbede JO (2016) Effect of diet containing Alchornea cordifolia leaf meal on performance and digestibility of Weaner rabbits. World Rabbit Sci. 24:201-206

Bancroft TD, Stevens A, Turner DR (1996) Theory and practice of histological technique, 4th edn. Churchill, Livingstone, New York

Benderitter M, Maupoli V, Vergely C, Dalloz F, Briot F, Rochette L (1998) Studies by electron paramagnetic resonance of the importance of iron in hydroxyl scavenging properties of ascorbic acid in plasma: effect of iron chelator. Fundamen Clin Pharmacol 12:510-643

Brunner JH (1984) Direct spectrophotometer determination of saponin. Animal Chem 34:1324-1326

Chukwuebuka E, Chinenye IJ (2015) Biological functions and anti-nutritional effects of phytochemicals in living system. J Pharm Biol Sci 10(2):10-19

Duncan DB (1955) Multiple range and multiple F-tests. Biometrics 11:1-42

Fallah R, Kiani A, Azarfar A (2013) A review of the role of five kinds of alternatives to in-feed antibiotics in broiler production. J Vet Med Anim Health. 5(11): 317-321

Gonzalez RM, Angeles HJC (2017) Antibiotic and synthetic growth promoters in animal diets. Review of impact and analytical methods. Food Cont 72:255267. https://doi.org/10.1016/j.foodcont.2016.03.001

Gyamfi MA, Yonamine M, Aaniya Y (1999) Free radical scavenging action of medicinal herbs from Ghana: Thonningia sanguine on experimentally induced liver injuries. General Pharmacol 32:661-667

Hassan HMA, Youssef AW, El-Daly EF, Abd El-Azeem NA, Hassan ER, Mohamed MA (2014) Performance, caecum bacterial count and ileum histology of broiler fed different direct-fed microbials. Asian J Poult. Sci 8(4):106-114

Ishibashi H, Komori A, Migita K, Nakamura M, Shimoda S (2009) Liver architecture, cell function, and disease. Sem Immunopathol 31(3):399-409

Julaeha E, Permatasari Y, Mayanti T, Diantini A (2014) Antifertility compound from the seeds of Carica papaya. Procedia Chem 17:66-69

Kadiri O, Olawoye B, Fawale OS, Adalumo OA (2016) Nutraceutical and antioxidant properties of the seeds, leaves, and fruits of Carica papaya: Potential relevance to human diets, the food industry, and the pharmaceutical industry - a review. Turkish J Agric Techn. 4(2):1039-1052

Kobayashi H, Wang C, Pomper KW (2008) Phenolic content and antioxidant capacity of Pawpaw fruit (Asimina triloba L.) at different ripening stages. Hortscience 43:268-270

Lohiya NK, Manivannan B, Mishra PK, Pathak N, Sriram S, Bhande SS, Panneerdoss $S$ (2002) Chloroform extract of Carica papaya seeds induces long-term reversible azoospermia in Langur monkey. Asian J Androl. 4(1):17-26

Maisarah AM, Asmah R, Fauziah O (2014) Proximate analysis, antioxidant and antiproliferative activities of different parts of Carica papaya. J Nutr Food Sci 4:2

Marra F, Aleffi S, Glastri S, Provenzano S (2009) Mononuclear cells in liver fibrosis. Sem Immunopathol 31(3):345-358

Mitruka BM, Rawnsley HM (1977) Clinical biochemical and hematological reference values in normal experimental animals. Masson Publishing USA, Inc., pp 134-139

Naito M, Hasegawa G, Takahashi K (1997) Development, differentiation, and maturation of Kupffer cells. Microsc Res Tech 39:350-364

NRC (1994) National Research Council. Nutrient requirements of poultry, 9th Revised Edition. National Academy Press, Washington D.C

Nurcahyani N, Busman H, Satyarso S, Rwhmawati PD, Kanedi M (2018) Antispermatogenic effect of seeds extract of papaya (Carica papaya) in Mice. The Pharma Chem J 5(4):18-22

Oloruntola DA, Dada EO, Osho IB, Ogundolie OO (2017) Effects of hydroethanolic leaf extract of Tithonia diversifolia on parasitaemia level, serum metabolites and histopathology of organs in Swiss Albino mice infected with Plasmodium berghei NK65. Asian J Med. Health 6(2):1-7

Oloruntola OD (2018) Serum biochemistry and histological studies in growing rabbits fed diets supplemented with Mucuna pruriens leaf meal. Arch Current Res Int 15(1):1-10

Oloruntola OD, Agbede JO, Ayodele SO, Ayedun ES, Daramola OT, Oloruntola DA (2018b) Gliricidia leaf meal and multi-enzyme in rabbit diet: effect on performance, blood indices, serum metabolites and antioxidant. J Anim Sci Techn 10:24. https://doi.org/10.1186/s40781-018-0182-8

Oloruntola OD, Agbede JO, Ayodele SO, Oloruntola DA (2018c) Neem, pawpaw and bamboo leaf meal dietary supplementation in broiler chicken: Effect on 
performance and health status. J Food Biochem 2018:e12723. https://doi. org/10.1111/jfbc.12723

Oloruntola OD, Ayodele SO (2017) Pawpaw leaf meal and exo-enzyme in rabbit: Effect on haematological and serum biochemical indices. Asian J Adv Agric Res 2(4):1-8

Oloruntola OD, Ayodele SO, Agbede JO, Asaniyan EK (2016c) Performance and digestibility of broiler starter fed diets containing Gliricidia sepium leaf meal. Asian J Biol Life Sci 5(1):97-102

Oloruntola OD, Ayodele SO, Agbede JO, Oloruntola DA (2016b) Effect of feeding broiler chicken with diets containing Alchornea cordifolia leaf meal and enzyme supplementation. Arch de Zootec 65(252):489-498

Oloruntola OD, Ayodele SO, Agbede JO, Oloruntola DA, Ogunsipe MH, Omoniyi IS (2016a) Effect of Alchornea cordifolia leaf meal and enzyme supplementation on growth, haematological, immunostimulatory and serum biochemical response of rabbits. Asian J Biol Life Sci 5(2):190-195

Oloruntola OD, Ayodele SO, Oloruntola DA (2018a) Effect of pawpaw (Carica papaya) leaf meal and dietary enzymes on broiler performance, digestibility, carcass, and blood composition. Rev Elev Med Vet Pays Trop 71:3. https://doi. org/10.19182/remvt

Pulido R, Bravo L, Saura-Calixto F (2002) Antioxidant activity of dietary polyphenols as determined by a modified ferric reducing/antioxidant power assay. J Agric Food Chem 48:3396-3402

Shastry GA (1983) Veterinary clinical pathology, 2nd edn. CBS Publishers and Distributors, New Delhi

Soetan KO, Oyewole OE (2009) The need for adequate processing to reduce the antinutritional factors in plants used as human foods and animal feeds: A review. African J Food Sci 3(9):223-232

Sofowora A (1993) Medicinal Plants and traditional medicine in Africa. Spectrum Books Ltd, Ibadan, Nigeria

SPSS (2011). Statistical package for social scientists. Version 20. www. spss.com.

Udoh P, Kehinde A (1999) Studies on antifertility effect of pawpaw seeds (Carica papaya) on the gonads of male albino rats. Phytother. Res. 13(3):226-228. https://doi.org/10.1002/(SICl) 1099-1573(199905)13:3<226:AID-PTR396>3.0.CO;2-E

Valenzuela-Grijalva NV, Pinelli-Saavedra AP, Muhlia-Almazan A, Dominguez-Diaz D, Gonzalez-Rios H (2017) Dietary inclusion effects of phytochemicals as growth promoters in animal production. J Anim Sci Tech 59:8. https://doi. org/10.1186/s40781-017-0133-9

Wenk C (2003) Herbs and botanicals as feed additives in monogastric animals. Asian-Australian J Anim Sci 16(2):282-289

Wick MJ, Leithäuser F, Reimann J (2002) The hepatic immune system. Crit Rev Immunol 22:47-103

\section{Publisher's Note}

Springer Nature remains neutral with regard to jurisdictional claims in published maps and institutional affiliations.

\section{Submit your manuscript to a SpringerOpen ${ }^{\circ}$ journal and benefit from:}

- Convenient online submission

- Rigorous peer review

- Open access: articles freely available online

- High visibility within the field

- Retaining the copyright to your article

Submit your next manuscript at $\boldsymbol{\nabla}$ springeropen.com 